\title{
Life history variation along a salinity gradient in coastal marshes
}

\author{
Shannon B. Martin ${ }^{1,2, *}$, Alan T. Hitch ${ }^{1,3}$, Kevin M. Purcell ${ }^{1,4}$, Paul L. Klerks ${ }^{1}$, \\ Paul L. Leberg ${ }^{1}$ \\ ${ }^{1}$ Department of Biology, University of Louisiana at Lafayette, Lafayette, Louisiana 70504, USA \\ ${ }^{2}$ Present address: Florida Fish and Wildlife Conservation Commission, Fish and Wildlife Research Institute, \\ Apalachicola Field Laboratory, Eastpoint, Florida 32328, USA \\ ${ }^{3}$ Present address: School of Forestry and Wildlife Sciences, Auburn University, Auburn, Alabama 36849, USA \\ ${ }^{4}$ Present address: Department of Biological Sciences, North Dakota State University, Fargo, North Dakota 58105, USA
}

\begin{abstract}
Coastal habitats are susceptible to changes in the environment associated with alterations in salinity. A field study was conducted on natural populations of the sailfin molly Poecilia latipinna, the western mosquitofish Gambusia affinis and the least killifish Heterandria formosa collected from coastal marsh sites along a salinity gradient, to investigate the influence of salinity on body condition and reproductive life history traits. In brackish marsh sites male $P$. latipinna had the best body conditions, while females had similar body conditions across all 3 marsh types. Female $P$. latipinna had greater reproductive allotment and fecundity in brackish marshes, where this fish was most abundant. Specimens of $G$. affinis collected from fresh marsh sites had less favorable body condition, and females had lower reproductive allotment and fecundity than those collected from higher salinities. While G. affinis was more abundant in freshwater marshes than in higher salinity marshes, this higher abundance did not correspond with a better body condition or higher reproductive effort, suggesting that $G$. affinis may be stressed in freshwater. There was no difference in the conditions between (both male and female) $H$. formosa from fresh and intermediate marshes. Female $H$. formosa from fresh marshes had a similar reproductive allotment and lower fecundity than those from intermediate marshes. The 3 species exhibited different life history patterns along the salinity gradient, and some of these patterns conflicted with expectations based on species abundances. When assessing habitat quality along an environmental gradient, measures of abundance should be accompanied by more sensitive indicators of environmental stress.
\end{abstract}

KEY WORDS: Sea level rise - Saltwater intrusion - Environmental stress $\cdot$ Environmental stability hypothesis · Density dependence $\cdot$ Gambusia affinis $\cdot$ Heterandria formosa $\cdot$ Poecilia latipinna

Resale or republication not permitted without written consent of the publisher

\section{INTRODUCTION}

Coastal habitats are continually changing because they lie at the interface between land and sea. This dynamic interaction makes coastal systems highly vulnerable to natural disturbances and climate change. Coastal environments are affected by storms, waves, and rainwater runoff, and changes in water temperature, currents, winds, and solar radiance, as well as sea level (Bindoff et al. 2007, Nicholls et al. 2007). Salinity levels may also change, since tropical storms, prevail- ing winds, and rising sea levels can drive saltwater inland into lower-salinity coastal areas (Titus \& Richman 2001, Nicholls et al. 2007). This saltwater intrusion is expected to become more prevalent as climates warm and sea levels rise, especially in areas such as the northern Gulf of Mexico that have a shallow coastal slope (Titus \& Richman 2001). Louisiana is experiencing some of the highest rates of relative sea level rise (i.e. eustatic sea level coupled with subsidence) globally (1.0 to $1.2 \mathrm{~cm} \mathrm{yr}^{-2}$ ) (Penland \& Ramsey 1990, Bindoff et al. 2007). Tidally influenced coastal 
marshes are delineated along an environmental gradient, with salinity levels decreasing farther inland (Odum 1988, Mitsch \& Gosselink 2000) and are susceptible to saltwater intrusion.

Changes in salinity can stress aquatic organisms residing in coastal marshes. It may be possible to detect salinity stress before it reaches lethal levels by examining variation in key life history traits of resident organisms along a salinity gradient. Salinity changes may result in stress due to the demands of maintaining osmotic balance (Nordlie 2006). The energetic costs of dealing with stress and concurrently maintaining homeostasis may constitute a substantial portion of the organism's energy budget and leave less energy available for other functions (i.e. locomotion, growth, and reproduction) (Sibly \& Calow 1989). As much as $25 \%$ of the energy remaining after basic maintenance requirements are met may be required to cope with a mild or brief disturbance (Wedemeyer et al. 1990). Life history theory predicts that energy should then be reallocated to physiological maintenance of an organism at the expense of growth and reproduction (Sibly \& Calow 1989, Stearns 1992). This response to stress could be detected by observing tactical changes in key life history traits such as age and size at maturity, reproductive allotment, and number and size of offspring (Roff 1992, Stearns 1992). Even population declines as observed in fishes (Adams et al. 2003) and amphibians (Blaustein \& Kiesecker 2002) may be due to exposure to sublethal stress affecting the survival and reproduction of a population's members. The stress may reduce an individual's health and performance, which directly influences its fitness by way of reduction in reproduction and/or survival through increased susceptibility to disease or predation (Wedemeyer et al. 1990). Tradeoffs between responses to salinity stress and biotic factors such as competition or predation can influence the occurrence of species and thus community structure (Dunson \& Travis 1991).

Some of the most common resident fishes inhabiting the vegetated margins of fresh and brackish marshes of the northern Gulf of Mexico are the sailfin molly Poecilia latipinna, the western mosquitofish Gambusia affinis, and the least killifish Heterandria formosa (Martin 1980, Gelwick et al. 2001, Lorenz \& Serafy 2006). These 3 species of livebearing fishes belong to the family Poeciliidae (Rosen \& Bailey 1963). After a lengthy step-wise acclimation process, all 3 species can tolerate a relatively broad range of salinity levels, at least for a short period of time (Meffe \& Snelson 1989). H. formosa is the least tolerant of elevated salinity levels, with a tolerance range of 0 to 20 ppt (S. Martin pers. obs.), followed by $G$. affinis, with a range of 0 to 58.5 ppt (Chervinski 1983), and P. latipinna is the most tolerant (0 to 80 ppt) (Nordlie et al. 1992). Even though these 3 species occur along a salinity gradient of coastal marshes in Louisiana, their relative abundances differ with salinity: $H$. formosa and $G$. affinis occur at higher densities at fresh marshes, while $P$. latipinna occurs at higher densities in intermediate and brackish marshes (A. T. Hitch et al. unpubl. data). These salinity preferences may not, however, be static, as Purcell et al. (2008) reported that $G$. affinis from brackish marshes were locally adapted to elevated salinity. Poeciliids may serve as a good indicator species of environmental change given their opportunistic life history strategy (Winemiller \& Rose 1992) through their plastic and quantifiable life history traits.

Some teleosts can only successfully reproduce within a more narrow range of salinities in which they occur (Griffith 1974). Because accelerated sea level rise and consequent saltwater intrusion might negatively affect coastal marsh fish populations, our objective was to examine the variation in body condition and reproductive life history traits in natural populations of poeciliids that reside along a salinity gradient of coastal marshes. If the local salinity creates chronic sublethal stress, then the energy allocated to additional osmoregulation and the response to stress could reduce the resources allocated to reproduction. The diverted energy allocated towards maintenance could affect life history traits such as adult size, body condition, reproductive allotment, fecundity, as well as the timing and level of offspring provisioning (i.e. lecithotrophy or matrotrophy). The 3 species in the present study differ in various characteristics: (1) salinity tolerance: Heterandria formosa < Gambusia affinis < Poecilia latipinna, (2) maternal provisioning: G. affinis < P. latipinna < $H$. formosa (Reznick \& Miles 1989), and (3) body size: $H$. formosa $<G$. affinis $<P$. latipinna. On the basis of these differences, and assuming that salinity stress is the major factor affecting differences in interspecific energy allocation along a salinity gradient, we predicted that $H$. formosa and $G$. affinis should be in better body condition, show higher reproductive allotment and produce more and larger offspring in freshwater marshes, while $P$. latipinna should perform better in habitats with higher salinity levels such as brackish marshes. In addition to our results, we will discuss how factors varying along the gradient in association with salinity might confound these predictions.

\section{MATERIALS AND METHODS}

Field collections. Individuals of Gambusia affinis, Heterandria formosa, and Poecilia latipinna were collected from May to August 2005 from populations along a coastal salinity gradient from fresh (0 to $1 \mathrm{ppt}$ ), intermediate (1 to $8 \mathrm{ppt}$ ), to brackish ( 8 to $15 \mathrm{ppt}$ ) marshes 
in the Terrebonne Basin of southeastern Louisiana (Fig. 1). Five sites were sampled in each marsh type. We chose this region of coastal Louisiana due to its history of saltwater intrusion events and high susceptibility to relative sea level rise (Penland \& Ramsey 1990, Louisiana Coastal Wetlands Conservation and Restoration Task Force and the Wetlands Conservation and Restoration Authority 1998). Because salinity levels can be highly variable in coastal marshes, we used the dominant emergent marsh vegetation as a proxy for the average salinity at a site (Visser et al. 1998). The dominant emergent vegetation at our fresh marsh sites ( 0 to 1 ppt) was Panicum hemitomon and Typha latifolia. Intermediate marsh sites (1 to $8 \mathrm{ppt}$ ) were dominated by Sagittaria lancifloia and Scirpus americanus, and brackish marsh sites (8 to $15 \mathrm{ppt}$ ) were dominated by Spartina patens and Juncus romerianus. Additionally, at each site, we measured the water temperature, dissolved oxygen concentration, and salinity with a YSI 85 meter (Table 1); marsh communities were associated with observed levels of salinity in the expected fashion. The sampling sites for each marsh type were at least $2 \mathrm{~km}$ apart. The dispersion of the sites is fairly similar; the largest distances between sites were $14.5 \mathrm{~km}$ in fresh marsh, $13 \mathrm{~km}$ in intermediate marsh, and $11 \mathrm{~km}$ in brackish marsh (Fig. 1). Sampling was limited to por- tions of the marsh to which we could obtain legal access, and the distribution of sites in the brackish marsh was somewhat constrained by the limited distribution of Gambusia affinis in that marsh type.

Individuals of each species were collected at each sampling site using dip nets $(33 \times 43 \mathrm{~cm}$ frame, with a $46 \mathrm{~cm}$ deep bag of $3 \mathrm{~mm}$ mesh) along the marsh shoreline in the emergent vegetation and in shallow areas (>1 m deep) containing submerged aquatic vegetation. Insufficient Heterandria formosa were collected from brackish marsh sites; therefore, we report only data for this species collected from fresh and intermediate marshes. Fishes were brought back to the field station at Mandalay National Wildlife Refuge (Houma, LA), then euthanized with MS-222, and fixed in $10 \%$ buffered formalin solution. After $72 \mathrm{~h}$, the specimens were rinsed with water and preserved in $70 \%$ ethanol for subsequent life history analyses.

The preserved specimens were sorted by species and gender. The criteria for sexual maturity of males was the presence of a fully formed gonopodium (Turner 1941), while for females it was the presence of an anal spot (i.e. dark concentration of melanophores appearing above the gonoduct; Farr \& Travis 1986, Constantz 1989). We measured the standard length (SL) of fish using digital calipers to the nearest

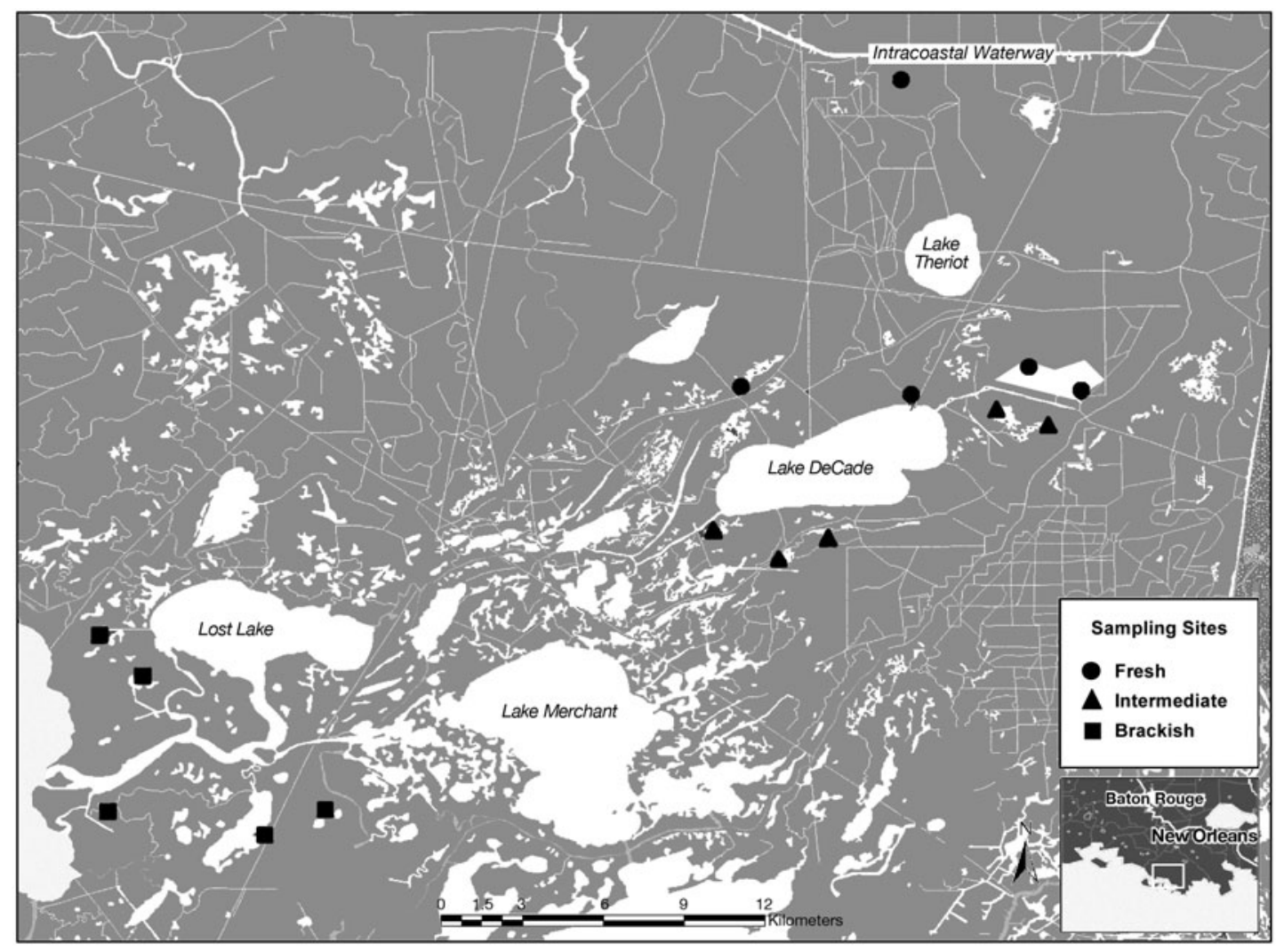

Fig. 1. Map of coastal marsh sampling sites in Terrebonne Basin, Louisiana, USA 
Table 1. Means (and ranges) for water quality parameters measured at each of the 5 sample sites within fresh, intermediate and brackish marshes, with overall mean \pm 1 SE for each marsh type

\begin{tabular}{|c|c|c|c|c|}
\hline Marsh type & Site & $\begin{array}{l}\text { Salinity } \\
\text { (ppt) }\end{array}$ & $\begin{array}{l}\text { Dissolved oxygen } \\
\left(\mathrm{mg} \mathrm{l}^{-1}\right)\end{array}$ & $\begin{array}{c}\text { Water } \\
\text { temperature }\left({ }^{\circ} \mathrm{C}\right)\end{array}$ \\
\hline \multirow[t]{6}{*}{ Fresh } & 1 & $0.17(0.1-0.2)$ & $3.47(0.6-7.2)$ & $26.73(23.4-31.6)$ \\
\hline & 2 & $0.83(0.7-1.0)$ & $4.34(0.4-12.1)$ & $26.07(15.2-32.1)$ \\
\hline & 3 & $0.37(0.1-0.6)$ & $3.35(0.4-9.0)$ & $23.83(13.9-30.3)$ \\
\hline & 4 & $0.80(0.6-1.0)$ & $1.83(0.7-4.0)$ & $23.90(14.9-29.9)$ \\
\hline & 5 & $0.47(0.2-0.9)$ & $2.36(0.8-4.4)$ & $23.07(18.5-26.8)$ \\
\hline & $\begin{array}{c}\text { Overall } \\
\text { mean }\end{array}$ & $0.53 \pm 0.09$ & $3.07 \pm 0.94$ & $24.72 \pm 1.63$ \\
\hline \multirow[t]{6}{*}{ Intermediate } & 1 & $1.73(1.2-2.1)$ & $3.80(1.1-5.4)$ & $25.63(22.7-30.6)$ \\
\hline & 2 & $2.30(1.4-3.2)$ & $3.11(0.6-6.8)$ & $27.77(23.3-32.0)$ \\
\hline & 3 & $1.87(1.6-2.1)$ & $3.33(0.4-6.1)$ & $28.17(23.1-33.2)$ \\
\hline & 4 & $2.87(1.6-4.1)$ & $3.18(0.3-7.2)$ & $25.77(15.4-31.0)$ \\
\hline & 5 & $2.83(1.5-4.3)$ & $3.13(0.3-8.7)$ & $27.10(15.1-33.8)$ \\
\hline & $\begin{array}{c}\text { Overall } \\
\text { mean }\end{array}$ & $2.32 \pm 0.24$ & $3.31 \pm 0.76$ & $26.89 \pm 1.68$ \\
\hline \multirow[t]{6}{*}{ Brackish } & 1 & $8.97(8.1-10.7)$ & $3.35(0.3-5.1)$ & $27.10(26.5-27.7)$ \\
\hline & 2 & $8.67(7.9-9.4)$ & $5.25(0.7-8.4)$ & $27.77(26.8-28.8)$ \\
\hline & 3 & $8.77(8.0-9.7)$ & $4.45(0.7-8.5)$ & $27.30(25.2-29.4)$ \\
\hline & 4 & $9.73(8.9-10.9)$ & $6.40(0.7-10.2)$ & $26.50(23.7-28.0)$ \\
\hline & 5 & $10.47(8.8-12.8)$ & $3.56(0.1-6.3)$ & $26.87(22.0-30.5)$ \\
\hline & $\begin{array}{l}\text { Overall } \\
\text { mean }\end{array}$ & $9.32 \pm 0.35$ & $4.60 \pm 0.89$ & $27.11 \pm 0.55$ \\
\hline
\end{tabular}

$0.01 \mathrm{~mm}$. A subset of randomly selected females was dissected to remove reproductive tissues and developing embryos. The developmental stage of embryos was determined following the interpretation of Haynes (1995) of the 6-stage classification proposed by Reznick (1981). For each gravid female, embryos of the same developmental stage were pooled, dried in a gravity oven at $60^{\circ} \mathrm{C}$ for $24 \mathrm{~h}$, and measured for dry mass to the nearest $0.01 \mathrm{mg}$ using a digital, analytical balance. The dry mass of pooled embryo was then divided by the number of individual embryos within that group (i.e. processed together but data expressed as average mass per embryo). The relationship between SL and dry body mass (i.e. slope of the regression line) was used as an index of body condition (Anderson \& Neumann 1996). For each species, gravid females from each site were assessed for their reproductive allotment by determining the gonadosomatic index (GSI), which is the mass of reproductive tissues and embryos divided by the total mass of the female multiplied by 100 (Roff 1992). We also used these females to quantify fecundity or brood size (based on Embryo Stages 2 to 6). In poeciliid fishes, embryo size can be influenced by the stage of development (Haynes 1995). To control for the influence of developmental staging on size, we used only Stage 5 embryos (most frequent stage in each species) to ascertain the relationship between offspring size and number among marsh type. In addition, for Heterandria formosa we measured the number of simultaneously carried broods (i.e. the level of superfetation), the number of offspring per brood, and the offspring mass by developmental stage (Stages 3 to 6).

Statistical analyses. All statistical analyses were conducted using SAS Enterprise Guide 4.1 (SAS Institute 2007). Sample sizes for each treatment combination were unequal due to differences in abundances of mature individuals at the time of collection. No interspecific or intersexual analyses were conducted. Due to size differences between species and to control for any sexual size dimorphism, males and females were analyzed separately for each species. The hierarchical experimental design consisted of 5 sampling sites within each of 3 marsh types (fresh, intermediate, and brackish marshes). We sampled fish from 5 populations in each marsh type to avoid representing a marsh type by a single sample. Because of the need to control for covariates such as SL or brood size, individuals were the unit of replication. A nested analysis of covariance (ANCOVA) was used to address lack of independence of individuals relative to the population samples within marsh type. We used this ANCOVA analysis to examine effects of marsh type, each covariate, and interaction between the covariate and marsh type for each of the following traits: body condition of males and females, number of offspring, size, number of simultaneous broods, and number of offspring per brood.

In fishes, fecundity generally increases with female size (Roff 1992). Female SL and/or the number of offspring were used as covariates in ANCOVAs for all reproductive traits, except GSI, which is already normalized by female size. ANCOVA has been shown to be more appropriate for controlling the effects of body size on body condition than other condition indices (Packard \& Boardman 1988). We included GSI because of its widespread use in evaluations of the reproductive biology of poeciliids. Whenever a significant correlation was detected between a dependent variable and female SL or the number of embryos per female, we reported the least-squares means $( \pm 1 \mathrm{SE})$ for the results of the ANCOVA, controlling for the effects of the covariate. Data that did not meet the assumptions of the ANCOVA were log transformed, and these transformations had the desired effect in all cases. 
Because superfetation was common in Heterandria formosa, we used the REPEATED function in PROC MIXED (SAS Institute 2007). Each developmental stage (Stages 3 to 6) was treated as a repeated measurement of embryo mass from the same female. This approach allowed us to control for the lack of independence in embryo mass between broods of different developmental stages within an individual female. Whenever a significant difference was detected, a Tukey's post hoc multiple comparison test was conducted to find where the differences were between treatment effects. Interactions were removed from the models if they were not statistically significant $(\alpha=$ 0.05), and the remaining effects were assessed for these reduced models.

\section{RESULTS}

\section{Poecilia latipinna}

Male $P$. latipinna exhibited a significant lengthmass relationship $\left(F_{1,184}=1344.93 ; \mathrm{p}<0.001\right)$, but there was no significant interaction between log SL and marsh type on log dry mass (i.e. slopes were not significantly different; $F_{2,184}=0.65 ; p=0.521$; Fig. 2a). The
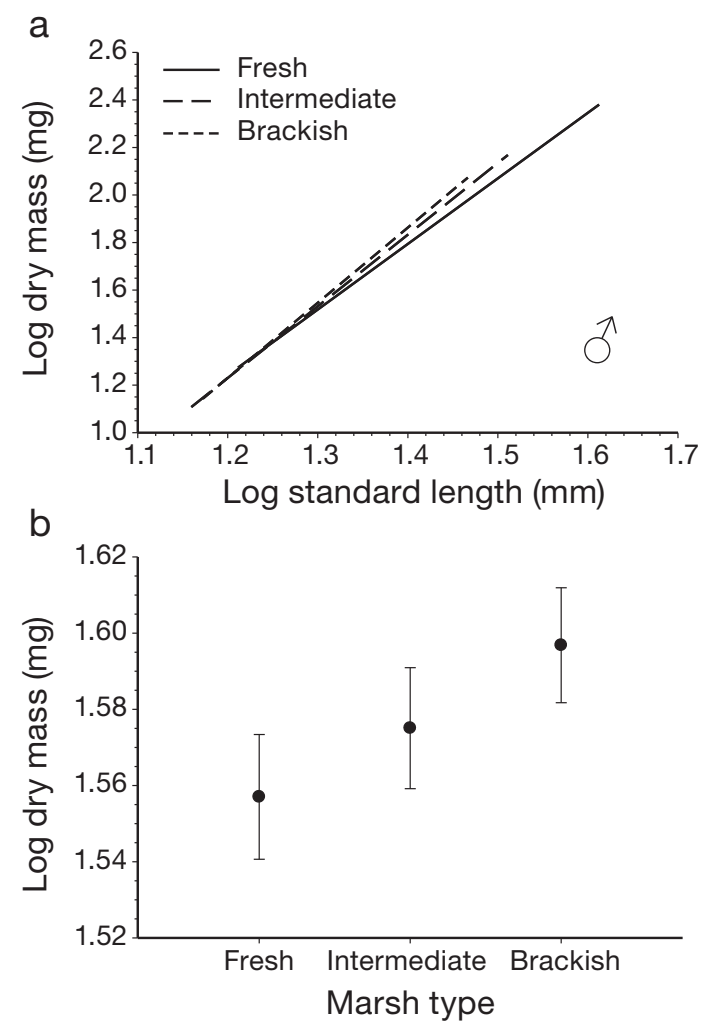

difference in body condition was determined by comparing least-square means after accounting for SL, given the parallel slopes of the regression lines. Males from brackish marshes had higher dry mass for their given SL (i.e. index of body condition) than those from fresh marshes $\left(F_{2,184}=3.94 ; \mathrm{p}=0.027 ;\right.$ Fig. $\left.2 \mathrm{a}, \mathrm{b}\right)$. Female $P$. latipinna exhibited a significant lengthmass relationship $\left(F_{1,336}=6976.84 ; \mathrm{p}<0.001\right)$, but there was no significant interaction between log SL and marsh type on log dry mass (i.e. slopes were equal; $F_{2,334}=0.38 ; \mathrm{p}=0.687 ;$ Fig. 2c). Females exhibited a similar index of body condition across marsh types $\left(F_{2,336}=0.40 ; \mathrm{p}=0.677 ;\right.$ Fig. $\left.2 \mathrm{c}, \mathrm{d}\right)$. When the slopes of regression lines were parallel, differences in female body condition were determined by the least-square means of dry somatic mass (e.g. Fig. 2c,d).

The amount of energy that females allocated to reproduction, measured as the GSI, differed between fish from the 3 marsh types $\left(F_{2,334}=4.02 ; \mathrm{p}<0.001\right)$. Females from brackish marshes exhibited a greater GSI than those from fresh marshes (Fig. 3a). The total number of offspring carried by a female was dependent on the female's SL (Fig. 3b), but this relationship was independent of the marsh type from which the fish were collected (i.e. slopes were not significantly different; $\left.F_{2,334}=0.73 ; \mathrm{p}=0.484\right)$. For their given size,
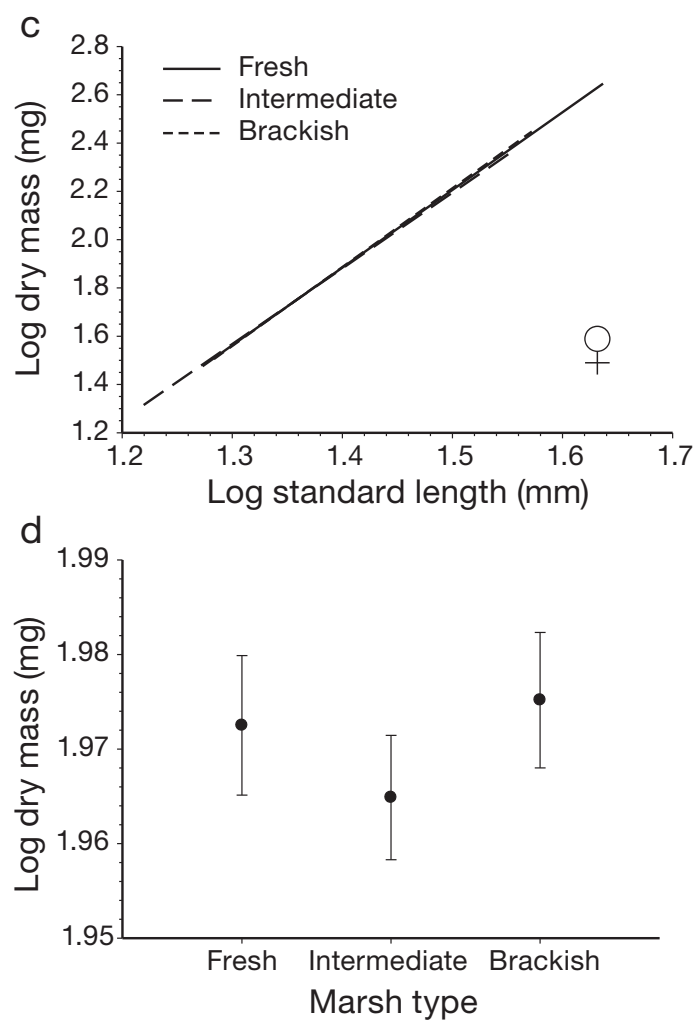

Fig. 2. Poecilia latipinna. (a) Relationship between standard length and body mass and (b) least-squares means ( \pm 1 SE) of dry mass of males collected from fresh, intermediate, and brackish marshes. (c) Relationship between standard length and body mass and (d) least-squares means $( \pm 1 \mathrm{SE})$ of dry mass of females collected from fresh, intermediate, and brackish marshes 

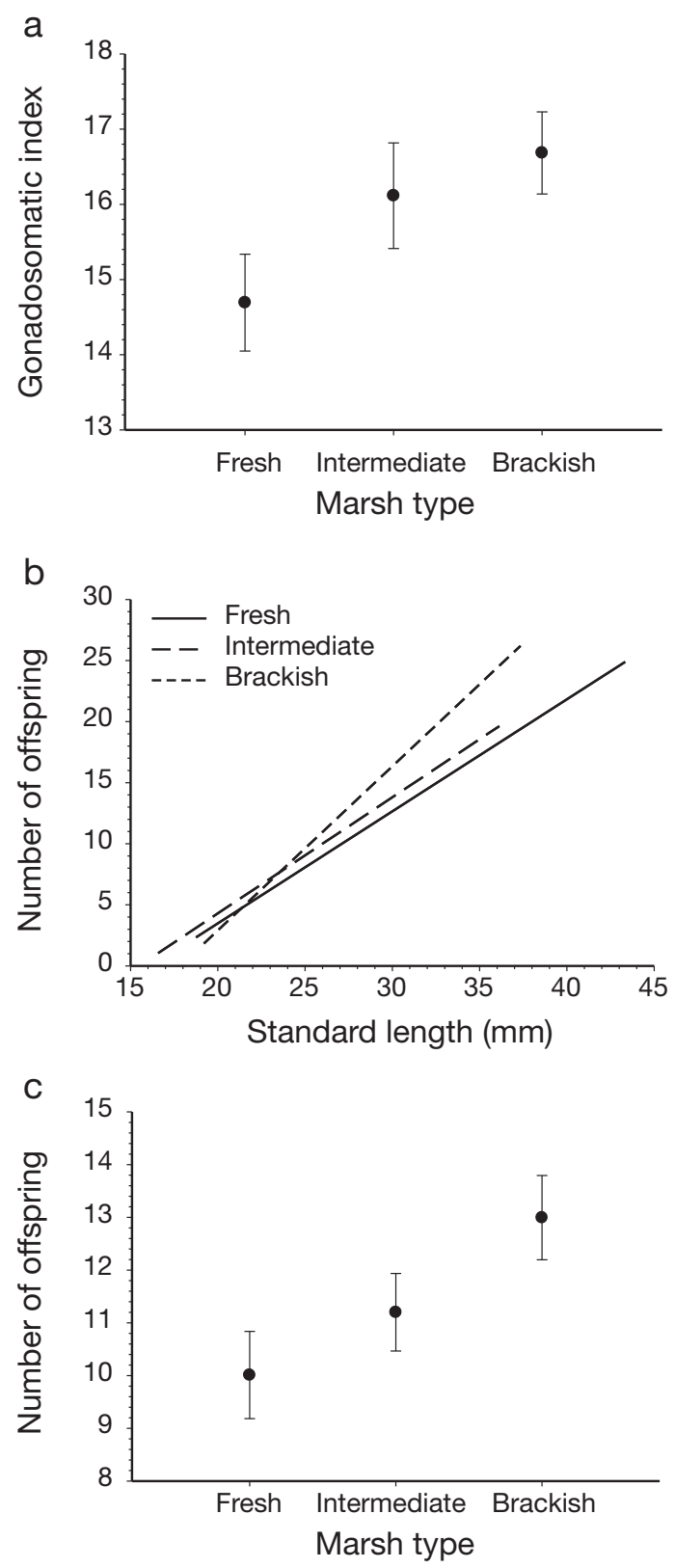

Fig. 3. Poecilia latipinna. (a) Gonadosomatic index, (b) relationship between standard length and fecundity, and (c) leastsquares means $( \pm 1 \mathrm{SE})$ for the number of offspring, adjusted for standard length, for females collected from fresh, intermediate, and brackish marshes

females from brackish marshes had more offspring than those from fresh and intermediate marshes $\left(F_{2,334}=\right.$ 3.56; $\mathrm{p}=0.049$; Fig. 3c). There was no significant interaction between SL and marsh type for the number of Stage 5 embryos carried by a female $\left(F_{2,100}=0.02 ; \mathrm{p}=\right.$ 0.979). Females produced more Stage 5 embryos for their given SL in brackish marshes compared to intermediate and fresh marshes $\left(F_{2,100}=7.04 ; \mathrm{p}=0.001\right.$; Table 2). Females from brackish marshes carried more Stage 5 embryos compared to those from intermediate
Table 2. Poecilia latipinna, Gambusia affinis and Heterandria formosa. Least-squares means $( \pm 1 \mathrm{SE})$ for offspring number (controlling for female standard length) and offspring size (controlling for offspring number at Stage 5 in embryonic development). P. latipinna and G. affinis were collected from fresh, intermediate and brackish marshes, while $H$. formosa were collected only from fresh and intermediate marshes ( $\mathrm{N}=$ female sample size)

\begin{tabular}{|lccc|}
\hline Marsh type & $\mathrm{N}$ & $\begin{array}{c}\text { Offspring } \\
\text { number }\end{array}$ & $\begin{array}{c}\text { Offspring } \\
\text { mass (mg) }\end{array}$ \\
\hline Poecilia latipinna & & & \\
$\quad$ Fresh & 31 & $12.2 \pm 1.2$ & $1.99 \pm 0.15$ \\
$\quad$ Intermediate & 41 & $11.6 \pm 0.5$ & $1.83 \pm 0.14$ \\
$\quad$ Brackish & 29 & $14.0 \pm 1.1$ & $1.76 \pm 0.15$ \\
Gambusia affinis & & & \\
$\quad$ Fresh & 84 & $6.4 \pm 0.7$ & $0.77 \pm 0.05$ \\
$\quad$ Intermediate & 82 & $7.0 \pm 0.7$ & $0.82 \pm 0.05$ \\
$\quad$ Brackish & 93 & $9.5 \pm 0.7$ & $0.74 \pm 0.04$ \\
Heterandria formosa & & & \\
$\quad$ Fresh & 112 & $2.5 \pm 0.2$ & $0.18 \pm 0.005$ \\
$\quad$ Intermediate & 91 & $2.9 \pm 0.2$ & $0.16 \pm 0.004$ \\
\hline
\end{tabular}

marshes. There was no significant interaction between the number of Stage 5 embryos and marsh type on size (i.e. measured as dry mass) of Stage 5 embryos $\left(F_{2,100}=\right.$ $2.97 ; \mathrm{p}=0.058)$. For a given number of Stage 5 embryos, there were no significant differences in the size of Stage 5 embryos among the different marsh types $\left(F_{2,100}=2.26 ; \mathrm{p}=0.109\right)$. Brood and offspring sizes are listed in Table 2.

\section{Gambusia affinis}

Male $G$. affinis exhibited a significant length-mass relationship $\left(F_{1,619}=1325.18 ; \mathrm{p}<0.001\right)$, but there was no significant interaction between SL and marsh type on log dry mass (i.e. slopes are not significantly different; $F_{2,619}=1.82 ; \mathrm{p}=0.162$; Fig. 4a). Males from fresh marshes had a lower index of body condition than those from intermediate and brackish marshes $\left(F_{2,619}=\right.$ 9.42; p $<0.0001$; Fig. 4a,b). Female G. affinis exhibited a significant length-mass relationship $\left(F_{1,419}=\right.$ 7839.78 ; $<0.0001)$, but there was no significant interaction between log SL and marsh type on log dry somatic mass (i.e. slopes are equal; $F_{2,417}=0.46 ; \mathrm{p}=$ 0.634; Fig. 4c). Females' index of body condition increased with increasing salinity levels $\left(F_{2,419}=9.78\right.$; $\mathrm{p}=0.003$; Fig. 4c,d).

We did detect significant differences among fish from different marsh types for GSI $\left(F_{2,420}=14.42 ; \mathrm{p}<\right.$ $0.001)$. Females allocated more resources for reproduction with increasing salinity levels (Fig. 5a). There was no significant interaction between SL and marsh type for the total number of offspring carried by a female 

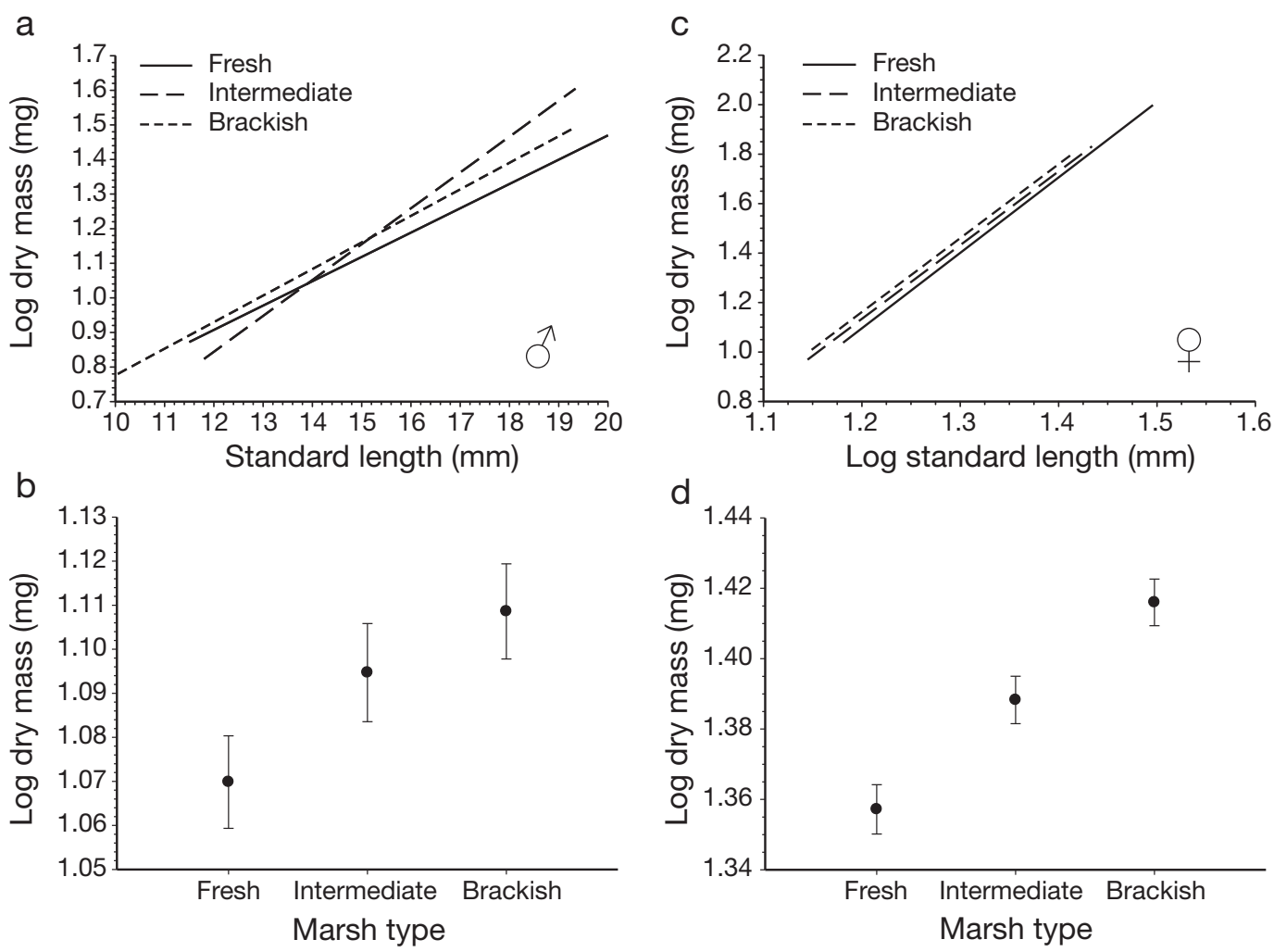

Fig. 4. Gambusia affinis. (a) Relationship between standard length and body mass and (b) least-squares means $( \pm 1$ SE) of dry mass of males collected from fresh, intermediate, and brackish marshes. (c) Relationship between standard length and body mass and (d) least-squares means ( $\pm 1 \mathrm{SE}$ ) of dry mass of females collected from fresh, intermediate, and brackish marshes

(i.e. slopes are not significantly different; $F_{2,420}=2.59$; $\mathrm{p}=0.076$; Fig. 5b). For their given size, females from fresh to intermediate to brackish marshes produced increasingly more offspring $\left(F_{2,420}=5.02 ; \mathrm{p}=0.008\right.$; Fig. 5c). Significant interaction was detected between SL and marsh type for the number of Stage 5 embryos carried by a female $\left(F_{2,258}=3.74 ; \mathrm{p}=0.025\right)$. Females produced more Stage 5 embryos for their given SL in brackish marshes compared to fresh and intermediate marshes $\left(F_{2,258}=3.07 ; \mathrm{p}=0.041\right)$ (Table 2). We detected significant interaction between the number of Stage 5 embryos and marsh type on the dry mass of Stage 5 embryos $\left(F_{2,258}=3.17 ; \mathrm{p}=0.044\right)$. Females from brackish marshes produced larger Stage 5 embryos than females from intermediate marshes, after controlling for the number of Stage 5 embryos $\left(F_{2,258}=4.40\right.$; $\mathrm{p}=0.013)$.

\section{Heterandria formosa}

Male $H$. formosa exhibited a significant length-mass relationship $\left(F_{1,258}=524.00 ; \mathrm{p}<0.001\right)$, but there was no significant interaction between SL and marsh type on log dry mass (i.e. slopes are not significantly differ- ent; $F_{1,258}=1.30 ; \mathrm{p}=0.256$; Fig. 6a). Males from fresh and intermediate marshes did not differ in body condition index $\left(F_{1,258}=1.04 ; \mathrm{p}=0.312\right.$; Fig. 6a,b). Female $H$. formosa exhibited a significant length-mass relation$\operatorname{ship}\left(F_{1,215}=1457.17 ; \mathrm{p}<0.0001\right)$, but this relationship was similar among females from different marsh types $\left(F_{1,215}=2.06 ; \mathrm{p}=0.153\right.$; Fig. 6c,d $)$.

Females from fresh and intermediate marshes had similar GSI $\left(F_{1,216}=0.20 ; \mathrm{p}=0.669 ;\right.$ Fig. $\left.7 \mathrm{a}\right)$. There was a significant relationship between female SL and fecundity $\left(F_{1,216}=133.69 ; \mathrm{p}<0.001\right)$, but we did not detect a significant interaction between female SL and marsh type for the total number of offspring (i.e. slopes are not significantly different; $F_{1,216}=1.22 ; \mathrm{p}=0.271$; Fig. $7 b$ ). For their given size, females from intermediate marshes had more total offspring than those from fresh marshes $\left(F_{1,216}=7.95 ; \mathrm{p}<0.0001 ;\right.$ Fig. $\left.7 \mathrm{c}\right)$. There was a significant relationship between female SL and the number of Stage 5 embryos carried by a female $\left(F_{1,202}=3.74 ; \mathrm{p}=0.025\right)$, but no significant interaction between female SL and marsh type for the number of Stage 5 embryos carried by a female $\left(F_{1,202}=0.18 ; \mathrm{p}=\right.$ 0.674). Females collected from intermediate marshes produced more Stage 5 embryos for their given SL compared to those from fresh marshes $\left(F_{1,202}=6.51\right.$; 

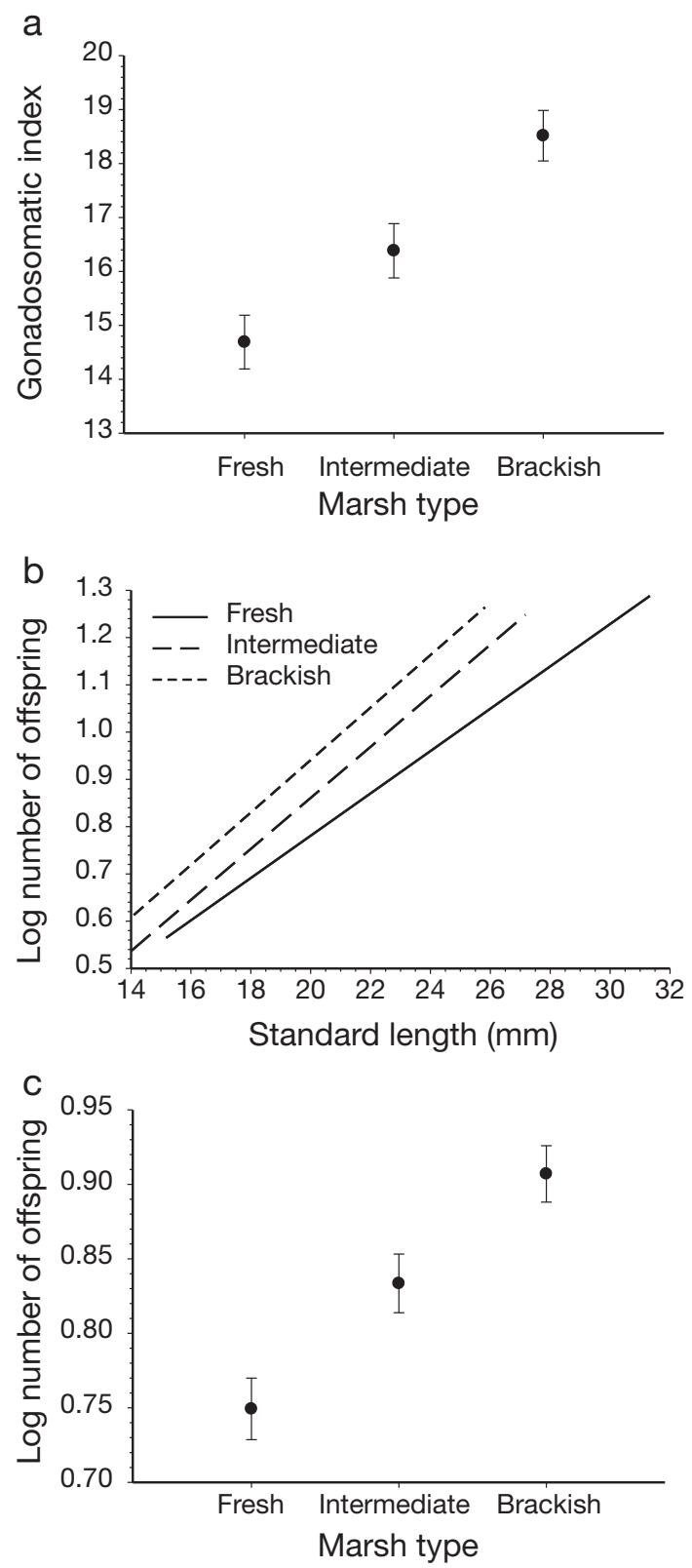

Fig. 5. Gambusia affinis. (a) Gonadosomatic index, (b) relationship between standard length and fecundity, and (c) leastsquares means $( \pm 1 \mathrm{SE})$ for the number of offspring, adjusted for standard length, for females collected from fresh, intermediate, and brackish marshes

$\mathrm{p}=0.012$ ) (Table 2). Females from intermediate marshes had a greater number of Stage 5 embryos compared to those from fresh marshes $\left(F_{1,202}=17.05\right.$; $\mathrm{p}<0.0001$ ), while females from fresh marshes produced Stage 5 embryos with greater dry mass for the given number of Stage 5 embryos carried than those from intermediate marshes $\left(F_{1,202}=13.74 ; \mathrm{p}=0.001\right)$.

We detected a significant interaction between marsh type and female SL on levels of superfetation or numbers of simultaneous broods carried $\left(F_{1,214}=6.33 ; \mathrm{p}=\right.$
0.013). Females from intermediate marshes exhibited higher levels of superfetation than did those from fresh marshes for their given SL (Fig. 8a). For their given SL, female Heterandria formosa collected from fresh marshes carried fewer numbers of simultaneous broods than those from intermediate marshes $\left(F_{1,214}=\right.$ $4.24 ; \mathrm{p}=0.041$; Fig. 8b). There was no significant interaction between female SL and marsh type for the number of offspring per brood $\left(F_{1,214}=1.23\right.$; $\left.p=0.268\right)$. Females from intermediate marshes had a greater number of offspring per brood than those from fresh marshes for their given SL $\left(F_{1,214}=10.67 ; \mathrm{p}=0.001\right.$; Fig. 8c). We also detected a significant interaction between marsh type and developmental stage for the dry mass of embryos in Stages 3 to $6\left(F_{3,214}=9.51 ; \mathrm{p}<\right.$ 0.001). Although there was no significant interaction between developmental stage and marsh type for offspring dry mass $\left(F_{3,214}=1.29 ; \mathrm{p}=0.278\right)$, we did detect significant differences in offspring sizes among fish from the 2 marsh types $\left(F_{1,214}=11.41 ; \mathrm{p}=0.001\right)$. Females from fresh marshes produced larger embryos at later developmental stages compared to females from intermediate marshes (Fig. 9).

\section{DISCUSSION}

Our primary goal was to document the variation in body condition and reproductive life history traits in natural populations of Poecilia latipinna, Gambusia affinis, and Heterandria formosa collected along a salinity gradient in coastal marshes susceptible to saltwater intrusion. We found significant variation in all traits examined, except for the body condition of $H$. formosa males and females and female P. latipinna (Table 3). Our results are congruent with those of Stearns \& Sage (1980) and Brown-Peterson \& Peterson (1990) for G. affinis and Trexler \& Travis (1990) for $P$. latipinna. Both the current study and the earlier reports found that females from higher salinity habitats exhibited greater reproductive allotment and fecundity than females collected in nearby lower-salinity sites. This pattern might be expected in sailfin mollies, which are generally most abundant in brackish marshes and have relatively high salinity tolerance. However, it is unclear why this pattern would occur in G. affinis, which has lower salinity tolerance and is generally more numerous in freshwater sites. It is uncertain whether differences in the number of embryos (controlling for female size) reflect typical brood sizes (Roff 1992, Stearns 1992) or differences in reproductive cycles among marsh types. The former is the more conventional interpretation, but, in either case, marsh type has an effect on reproductive allocation and fecundity. 

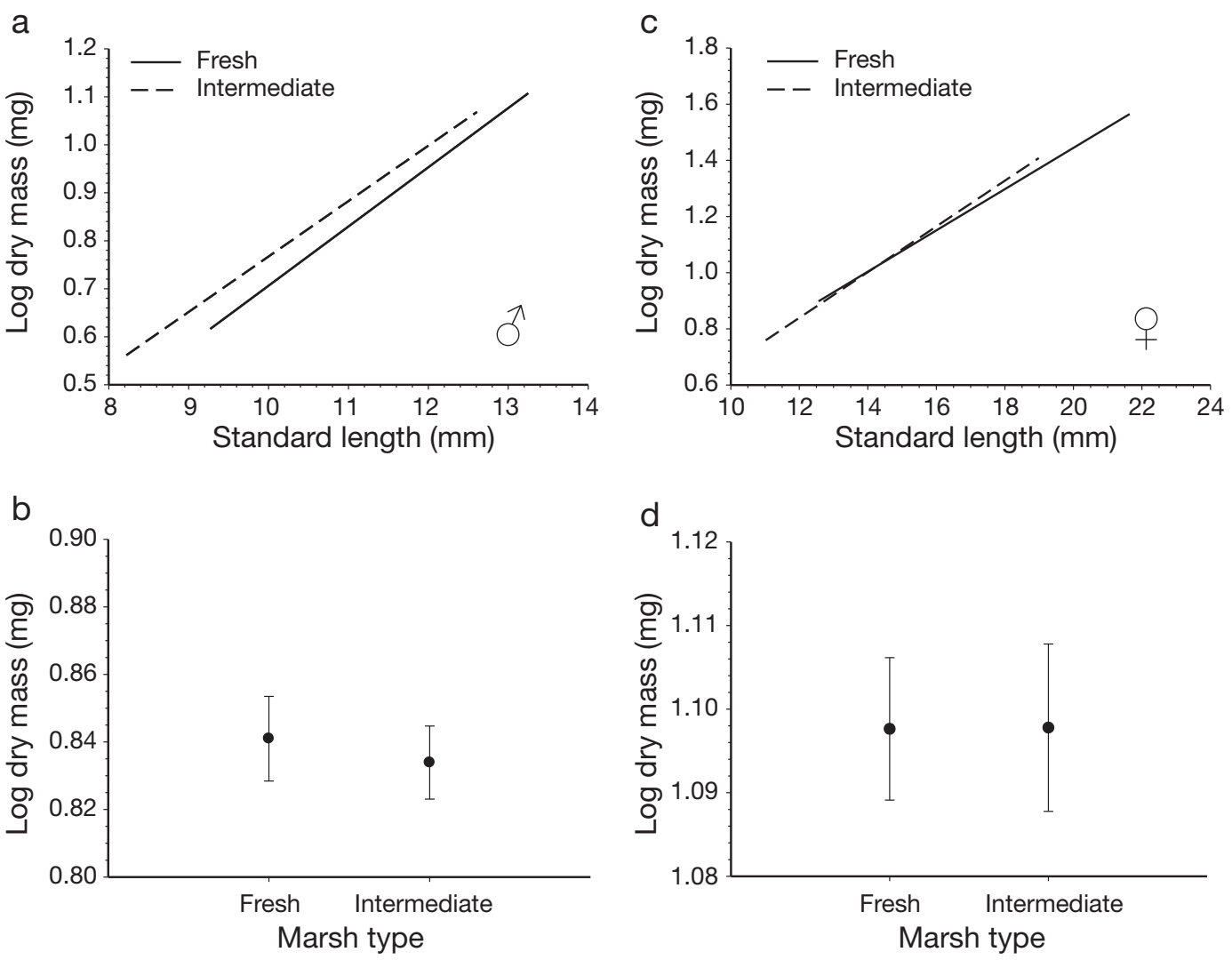

Fig. 6. Heterandria formosa. (a) Relationship between standard length and body mass and (b) least-squares means ( \pm 1 SE) of dry mass of males collected from fresh and intermediate marshes. (c) Relationship between standard length and body mass and (d) least-squares means $( \pm 1 \mathrm{SE})$ of dry mass of females collected from fresh and intermediate marshes

Male Poecilia latipinna and both male and female Gambusia affinis collected from fresh marsh sites had a lower body condition index. Females of both species collected from fresh marshes had lower reproductive allotment and fecundity than those collected from sites with higher salinities (i.e. intermediate and brackish marshes). The combined results suggested that $G$. affinis and $P$. latipinna are better adapted to marshes with higher salinity levels than to fresh marsh environments. Fishes examined here were collected from coastal marshes with salinities ranging from 0 to 12 ppt. These marshes did not only differ in average salinity level, but variability also increased with increasing salinity level of these coastal marsh habitats (Table 1), which has implications for the support of the 'environmental stability hypothesis' (Stearns 1983, Abney \& Rakocinski 2004). The 'environmental stability hypothesis' predicts that more environmentally variable habitats select for individuals that are younger and smaller at maturity, have higher reproductive allotment (per unit body mass), larger brood sizes, and smaller offspring size relative to individuals from more stable habitats (Stearns 1983, 1992).

Purcell et al. (2008) used populations of Gambusia affinis collected along a salinity gradient (in the same marshes as our study) to examine the survival times of individual mosquitofish that were exposed to an abrupt and lethal spike in salinity of 25 ppt. They found that G. affinis from brackish and intermediate marshes had increased tolerance to salinity stress com-

Table 3. Poecilia latipinna, Gambusia affinis, Heterandria formosa. Summary of results for dependent variables across marsh types (F: fresh; I: intermediate; B: brackish). Sample sizes in parentheses. o': male; o: female; GSI: gonadosomatic index

\begin{tabular}{|c|c|c|c|c|c|}
\hline \multirow[t]{2}{*}{ Species } & \multicolumn{2}{|c|}{ Body condition } & \multirow[t]{2}{*}{ GSI } & \multirow[t]{2}{*}{ Fecundity } & \multirow[t]{2}{*}{ Offspring size } \\
\hline & $0^{7}$ & ф & & & \\
\hline Poecilia latipinna & (202): F < B & $(352): F \approx I \approx B$ & $\mathrm{~F}<\mathrm{B}$ & $\mathrm{F} \approx \mathrm{I}<\mathrm{B}$ & $\mathrm{F} \approx \mathrm{I} \approx \mathrm{B}$ \\
\hline Gambusia affinis & (637): $\mathrm{F}<\mathrm{I} \approx \mathrm{B}$ & (435): $\mathrm{F}<\mathrm{I}<\mathrm{B}$ & $\mathrm{F}<\mathrm{I}<\mathrm{B}$ & $\mathrm{F}<\mathrm{I}<\mathrm{B}$ & $\mathrm{I}>\mathrm{B}$ \\
\hline Heterandria formosa & $(270): F \approx I$ & (226): F $\approx I$ & $\mathrm{~F} \approx \mathrm{I}$ & $\mathrm{F}<\mathrm{I}$ & $\mathrm{F}>\mathrm{I}$ \\
\hline
\end{tabular}



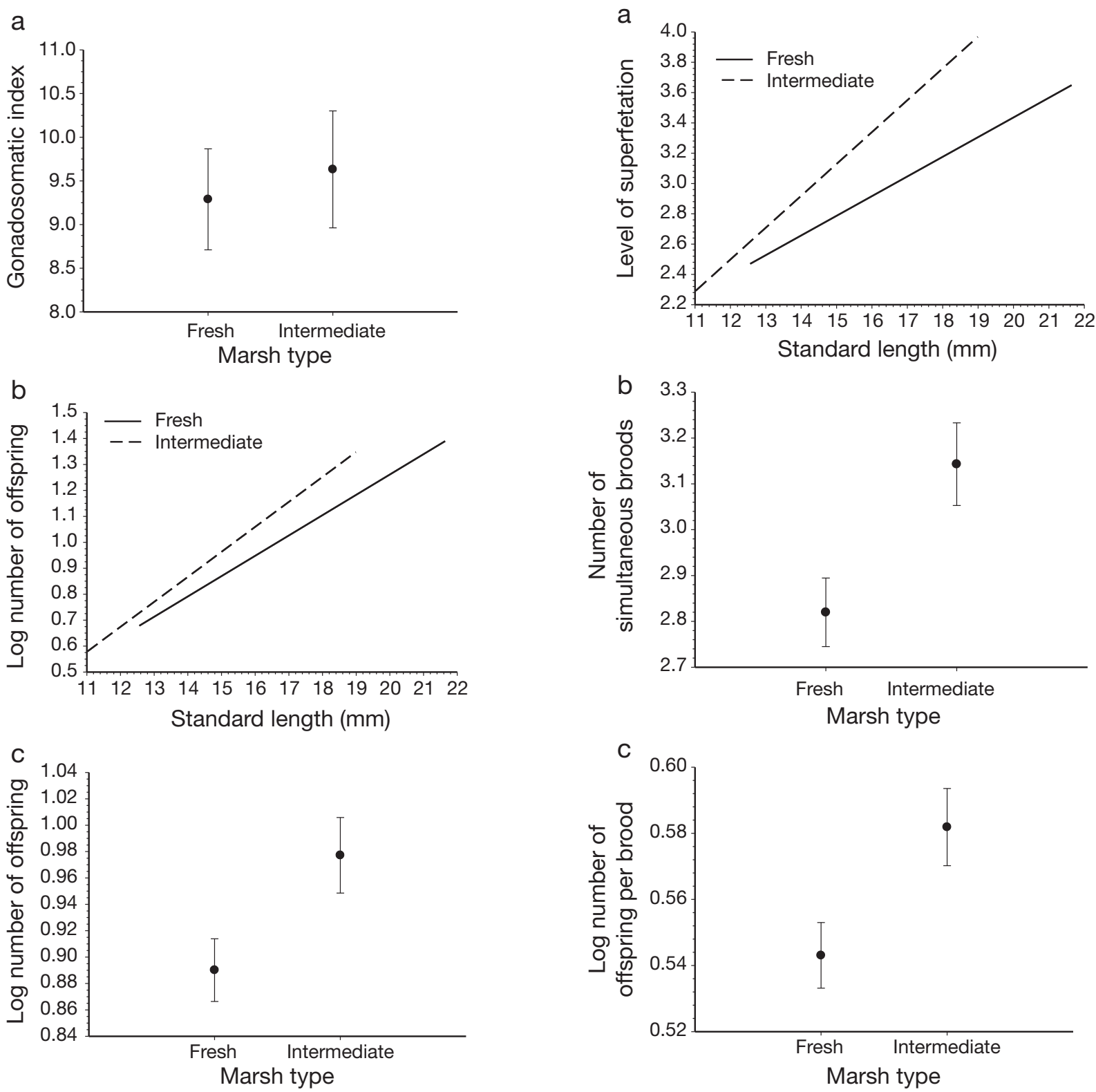

Fig. 7. Heterandria formosa. (a) Gonadosomatic index, (b) relationship between standard length and fecundity, and (c) least-squares means $( \pm 1 \mathrm{SE})$ for the number of offspring, adjusted for standard length, for females collected from fresh and intermediate marshes

pared to mosquitofish from freshwater environments and that salinity tolerance had a genetic basis (Purcell et al. 2008). However non-genetic factors also seem to play a role. For instance, when studies include lengthy acclimation periods, levels of salinity tolerance can be much higher than those obtained following abrupt salinity changes. Akin \& Neill (2004) suggested that salinities ranging from 0 to $20 \mathrm{ppt}$ do not impact the metabolic capacity of adult $G$. affinis, although they did observe a slight, but significant, reduction in respi-

Fig. 8. Heterandria formosa. (a) Relationship between standard length and level of superfetation, (b) least-squares means $( \pm 1 \mathrm{SE})$ for the number of simultaneous broods, adjusted for standard length, and (c) number of offspring per brood, adjusted for the number of broods carried by a female collected from fresh and intermediate marshes

ration rate at $10 \mathrm{ppt}$ relative to $0 \mathrm{ppt}$. Following a serial acclimation period of $14 \mathrm{~d}$ for every $5 \mathrm{ppt}$ increase in salinity starting at $0 \mathrm{ppt}$, the plasma osmotic concentrations of a freshwater population of G. holbrooki did not differ among fish exposed to salinity levels in the range of from 0 to 10 ppt (Nordlie \& Mirandi 1996). Similarly, survivorship did not differ among fish exposed to salinities ranging from 0 to $15 \mathrm{ppt}$ if this exposure was preceded by an acclimation period of $42 \mathrm{~d}$ (Nordlie \& Mirandi 1996). In Poecilia latipinna collected from 


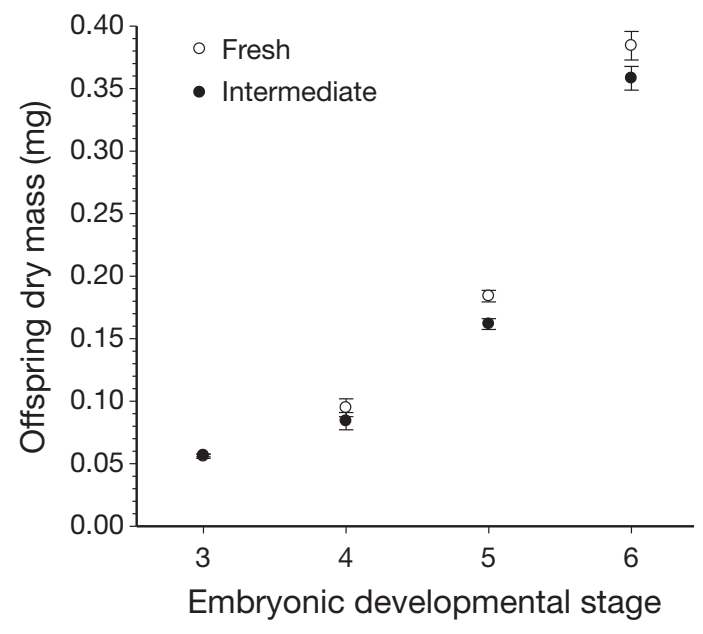

Fig. 9. Heterandria formosa. Mean offspring size by developmental stage for $H$. formosa collected from fresh $(\mathrm{N}=120)$ and intermediate marshes $(\mathrm{N}=106)$

freshwater and brackish (mean = 15 ppt) sites, the plasma osmotic concentrations did not significantly differ over the range of salinity levels of from 0 to $75 \mathrm{ppt}$, and survival was affected only for salinities $>70 \mathrm{ppt}$, where the brackish population had a higher survivorship (Nordlie et al. 1992). The environmental gradient along which we collected these fish ranged in salinity from 0.1 to $12.8 \mathrm{ppt}$, which is within the salinity tolerance limits of all 3 species. Despite their broad salinity tolerances, we did find significant variation in several important life history traits in all 3 species (i.e. body condition, GSI, fecundity, and offspring size).

Leips \& Travis (1999) reported variation in life history traits among freshwater populations of Heterandria formosa, which they attributed to differences in population densities and predation pressure. Our study is the first known report of life history variation in $H$. formosa along a salinity gradient. Surprisingly, for a freshwater fish, $H$. formosa collected from intermediate marshes had similar body condition index and reproductive allotment to those collected from freshwater marshes. Female $H$. formosa collected from fresh marshes also had a lower fecundity (albeit similar reproductive allotment) compared to those from intermediate marshes. These differences in fecundity, number of simultaneous broods, and number of offspring per brood were due to differences in the relationship between offspring number and size. Female $H$. formosa collected from fresh marshes produced fewer but larger offspring than females from intermediate marshes. Similarity in reproductive allotment, despite differences in offspring sizes and numbers, indicates a trade-off between offspring size and number. The pattern of larger offspring sizes of $H$. formosa in fresh marshes (where they were most abundant) was similar to that reported by Leips \& Travis (1999) for least killifish in freshwater habitats with greater population densities.

Life history theory predicts that females with equal reproductive allotment maximize lifetime fitness by producing fewer, larger offspring in stable environments, with higher juvenile mortality or higher levels of resource competition. Conversely, theory predicts that females in fluctuating environments with higher adult mortality or lower levels of resource competition should produce more, smaller offspring (Stearns 1992). Gomes \& Monteiro (2007) measured reproductive life history traits of the poeciliid fish Poecilia vivipara along a salinity gradient in Brazil and attributed the life history variation to differences in predation regime rather than differences in mean and variance of salinity. Although we collected fishes along a salinity gradient, other abiotic and biotic environmental factors (Dunson \& Travis 1991), such as food quantity and quality (Reznick 1990), population density (Hughes 1985, Leips \& Travis 1999), and predation pressure (Reznick et al. 1990, Johnson 2001), could covary with salinity and contribute to variation in life history traits. Controlled experiments should be conducted to assess the influence of the many environmental factors that vary along such a complex system as a salinity gradient on life history traits. Moreover, common-environment experiments (Martin 2008) are required to resolve whether variation in life histories were due to phenotypic plasticity or genetic differences between populations (Sibly 1999, Conner \& Hartl 2004).

Measures of relative abundance of target species are commonly used to assess habitat quality (Garshelis 2000, Pearce \& Ferrier 2001, Johnson 2007). In our study, both sailfin mollies and least killifish appeared to be in better condition in marsh types that also supported higher densities of fish; this is consistent with the expected association (based on theory) between habitat quality and both individual condition and population abundance. However, abundance does not necessarily equal productivity (Pulliam 1988). High abundance may reflect increased immigration rates rather than being indicative of high local productivity (Van Horne 1983). Body condition and life history traits associated with reproduction may be more effective measures of habitat quality. Variation in life history traits of organisms that live along an environmental gradient has important implications for stress tolerance, life history evolution, and the direct impact of abiotic factors on population demographics (Caswell 1983, Sibly \& Calow 1989, Stearns 1992). In our study, variation in the suite of traits we measured along a salinity gradient suggests that Gambusia affinis is stressed in fresh marshes. We found lower levels of body condition, lowered GSI, and lowered fecundity 
for $G$. affinis in fresh marshes, where these fish were most abundant, indicating that greater abundance did not correspond with better condition and higher reproductive capacity.

Limited evidence exists from other studies to suggest that freshwater would be more stressful to Gambusia affinis than those salinities observed in intermediate marshes (Stearns \& Sage 1980, Brown-Peterson \& Peterson 1990). Additionally, Akin \& Neill (2004) did report an increase in respiration rates in G. affinis at 0 ppt compared to at 10 ppt (though they did not feel this increased respiration would be stressful to the fish). If salinity is not responsible for our observation and those reported in other studies, some other environmental factor (possibly associated with the salinity level) may be influencing the increased abundance and decreased condition of $G$. affinis in freshwater marsh habitats relative to intermediate marshes. Our findings are similar to those obtained from studies conducted in marsh habitats in Texas (Stearns \& Sage 1980) and Mississippi (Brown-Peterson \& Peterson 1990), and suggest that the causal mechanism is somewhat consistent across time and space. Given the diverse effects of salinity on other components of marsh systems, it is impossible to do more than speculate on the biotic or abiotic factors that might explain these results if salinity itself is not the causal factor.

Bachman \& Rand (2008) reported that salinity stress due to acute, abrupt changes in salinity negatively impacted the survival and development in Gambusia holbrooki and Poecilia latipinna. Alcaraz \& GarciaBerthou (2007) found that as salinity increased G. holbrooki exhibited higher reproductive investment, a lower condition level, and a lower population density. We found that along a salinity gradient from fresh to brackish marshes (0 to $12 \mathrm{ppt}$ ), several important life history traits varied in natural populations of poeciliid fishes (Table 3). The patterns in variation of the suite of life history traits we measured did not support causation by any single factor, although these patterns fit best the predictions from the 'environmental stability hypothesis'. Moreover, in the case of G. affinis, embryo size and number (adjusted for SL) were smaller and the body condition level lower, despite higher densities. Further study is required to isolate the primary environmental factor influencing life history variation in these fishes from other potential environmental (e.g. predation pressure, population density, and food availability) and genetic effects (Martin 2008). Small-scale localized disturbance events (e.g. storm surges from tropical storms) and large-scale actions such as sea level rise and climate change will most likely influence the survival and reproduction of organisms that live along a coastal environmental gradient. Studies that examine the effects of salinity stress, such as this present investigation, are essential in understanding how global climate change and sea level rise will impact organisms residing within the coastal zone.

Acknowledgements. Comments by L. Rozas, J. Neigel, J. Albert, and several anonymous reviewers improved the original manuscript. We appreciate the assistance by $\mathrm{M}$. Collins (University of Louisiana at Lafayette) and the logistical support provided by P. Yakupzack (USFWS) at Mandalay National Wildlife Refuge. We thank the EPA National Center of Environmental Research and the Louisiana Board of Regents EPSCor for funding this project. Although the research described in this article has been funded, in part, by the United States Environmental Protection Agency through Grant R-82942001-0 to the Louisiana Board of Regents, it has not been subjected to the agency's peer and policy review process and therefore does not necessarily reflect the views of the agency and no official endorsement should be inferred. This research complied with all state and federal laws and was conducted following ethical requirements under the guidelines of the University of Louisiana at Lafayette Institutional Animal Care and Use Committee (IACUC No. 2004-8717-020).

\section{LITERATURE CITED}

Abney MA, Rakocinski CF (2004) Life-history variation in Caribbean gambusia, Gambusia puncticulata puncticulata (Poeciliidae) from the Cayman Islands, British West Indies. Environ Biol Fishes 70:67-79

Adams SM, Greeley MS, Law JM, Noga EJ, Zelikoff JT (2003) Application of multiple sublethal stress indicators to assess the health of fish in Pamlico Sound following extensive flooding. Estuaries 26:1365-1382

Akin S, Neill WH (2004) Routine metabolism of mosquitofish (Gambusia affinis) at three different salinities. Tex J Sci 55:255-262

> Alcaraz C, Garcia-Berthou E (2007) Life history variation of invasive mosquitofish (Gambusia holbrooki) along a salinity gradient. Biol Conserv 139:83-92

Anderson RO, Neumann RM (1996) Length, weight and associated structural indices. In: Murphy BR, Willis DW (eds) Fisheries techniques, 2nd ed. American Fisheries Society, Bethesda, MD, p 447-481

> Bachman PM, Rand GM (2008) Effects of salinity on native estuarine fish species in South Florida. Ecotoxicology 17: 591-597

Bindoff NL, Willebrand J, Artale V, Cazenave A and others (2007) Observations: oceanic climate change and sea level. In: Solomon S, Qin D, Manning M, Chen Z and others (eds) Climate change 2007: the physical science basis. Contribution of Working Group I to the 4th assessment report of the Intergovernmental Panel on Climate Change. Cambridge University Press, Cambridge, p 385-432

Blaustein AR, Kiesecker JM (2002) Complexity in conservation: lessons from the global decline of amphibian populations. Ecol Lett 5:597-608

Brown-Peterson N, Peterson MS (1990) Comparative life history of female mosquitofish, Gambusia affinis, in tidal fresh-water and oligohaline habitats. Environ Biol Fishes $27: 33-41$

Caswell H (1983) Phenotypic plasticity in life-history traits: demographic effects and evolutionary consequences. Am 
Zool 23:35-46

Chervinski J (1983) Salinity tolerance of the mosquitofish, Gambusia affinis (Baird and Girard). J Fish Biol 22:9-11

Conner JK, Hartl DL (2004) A primer of ecological genetics. Sinauer Associates, Sunderland, MA

Constantz GD (1989) Reproductive biology of poeciliid fishes. In: Meffe G, Snelson F (eds) Ecology and evolution of livebearing fishes (Poeciliidae). Prentice-Hall, Inc., Englewood Cliffs, NJ, p 33-50

Dunson WA, Travis J (1991) The role of abiotic factors in community organization. Am Nat 138:1067-1091

Farr JA, Travis J (1986) Fertility advertisement by female sailfin mollies, Poecilia latipinna (Pisces, Poeciliidae). Copeia 1986:467-472

Garshelis DL (2000) Delusions in habitat evaluation: measuring use, selection, and importance. In: Boitani L, Fuller TK (eds) Research techniques in animal ecology: controversies and consequences. Columbia University Press, New York, p 111-164

Gelwick FP, Akin S, Arrington DA, Winemiller KO (2001) Fish assemblage structure in relation to environmental variation in a Texas Gulf coastal wetland. Estuaries 24:285-296

Gomes JL, Monteiro LR (2007) Size and fecundity variation in populations of Poecilia vivipara Block \& Schneider (Teleostei; Poeciliidae) inhabiting an environmental gradient. J Fish Biol 71:1799-1809

Griffith RW (1974) Environment and salinity tolerance in the genus Fundulus. Copeia 1974:319-331

Haynes JL (1995) Standardized classification of poeciliid development for life-history studies. Copeia 1995:147-154

Hughes AL (1985) Seasonal trends in body size of adult male mosquitofish, Gambusia affinis, with evidence for their social control. Environ Biol Fishes 14:251-258

Johnson JB (2001) Adaptive life-history evolution in the livebearing fish Brachyrhaphis rhabdophora: genetic basis for parallel divergence in age and size at maturity and a test of predator-induced plasticity. Evolution 55: 1486-1491

Johnson M (2007) Measuring habitat quality: a review. Condor 109:489-504

Leips J, Travis J (1999) The comparative expression of lifehistory traits and its relationship to the numerical dynamics of four populations of the least killifish. J Anim Ecol 68: $595-616$

Lorenz JJ, Serafy JE (2006) Subtroprical wetland fish assemblages and changing salinity regimes: implications for everglades restoration. Hydrobiologia 569:401-422

Louisiana Coastal Wetlands Conservation and Restoration Task Force and the Wetlands Conservation and Restoration Authority (1998) Coast 2050: toward a sustainable coastal Louisiana. Louisiana Department of Natural Resources, Baton Rouge, LA

Martin FD (1980) Poeciliidae-Livebearers. In: Lee DS, Gilbert CR, Hocutt CH, Jenkins RE, McAllister DE, Stouffer JR (eds) Atlas of North American freshwater fishes. North Carolina State Museum of Natural History, Raleigh, $\mathrm{NC}, \mathrm{p} 537-557$

Martin SB (2008) Reproductive strategies of coastal marsh fishes: assessing alternative life history tactics in response to environmental change. $\mathrm{PhD}$ dissertation, Department of Biology, University of Louisiana at Lafayette

Meffe G, Snelson F (1989) An ecological overview of poeciliid fishes. In: Meffe GK, Snelson FF (eds) Ecology and evolution of livebearing fishes (Poeciliidae). Prentice-Hall, Englewood Cliffs, NJ, p 13-31

Mitsch WJ, Gosselink JG (2000) Wetlands, 3rd edn. John Wiley, New York
Nicholls RJ, Wong PP, Burkett VR, Codignotto JO (2007) Coastal systems and low-lying areas. In: Parry ML, Canziani OF, Palutikof JP, Linden PJvd, Hanson CE (eds) Climate change 2007: impacts, adaptation and vulnerability. Contribution of Working Group II to the 4th Assessment Report of the Intergovernmental Panel on Climate Change. Cambridge University Press, Cambridge, p 315-356

Nordlie FG (2006) Physicochemical environments and tolerances of cyprinodontoid fishes found in estuaries and salt marshes of eastern North America. Rev Fish Biol Fish 16: 51-106

Nordlie FG, Mirandi A (1996) Salinity relationships in a freshwater population of eastern mosquitofish. J Fish Biol 49: $1226-1232$

> Nordlie FG, Haney DC, Walsh SJ (1992) Comparisons of salinity tolerances and osmotic regulatory capabilities in populations of sailfin molly (Poecilia latipinna) from brackish and fresh waters. Copeia 1992:741-746

>dum WE (1988) Comparative ecology of tidal freshwater and salt marshes. Annu Rev Ecol Syst 19:147-176

Packard GC, Boardman TJ (1988) The misuse of ratios, indices, and percentages in ecophysiological research. Physiol Zool 61:1-9

$>$ Pearce J, Ferrier S (2001) The practical value of modelling relative abundance of species for regional conservation planning. Biol Conserv 98:33-43

Penland S, Ramsey KE (1990) Relative sea-level rise in Louisiana and the Gulf of Mexico: 1908-1988. J Coast Res 6:323-342

Pulliam HR (1988) Sources, sinks, and population regulation. Am Nat 132:652-661

Purcell KM, Hitch AT, Klerks PL, Leberg PL (2008) Adaptation as a potential response to sea-level rise: a genetic basis for salinity tolerance in populations of a coastal marsh fish. Evol Appl 1:155-160

- Reznick D (1981) Grandfather effects: the genetics of interpopulation differences in offspring size in the mosquito fish. Evolution 35:941-953

Reznick D (1990) Plasticity in age and size at maturity in male guppies (Poecilia reticulata): an experimental evaluation of alternative models of development. J Evol Biol 3: 185-203

Reznick DN, Miles DB (1989) Review of life history patterns in poeciliid fishes. In: Meffe G, Snelson F (eds) Ecology and evolution of livebearing fishes (Poeciliidae). Prentice-Hall, Englewood Cliffs, NJ, p 125-148

Reznick D, Bryga H, Endler J (1990) Experimentally induced life-history evolution in a natural population. Nature 346 : 357-359

Roff DA (1992) The evolution of life histories. Chapman \& Hall, New York

Rosen DE, Bailey RM (1963) The poeciliid fishes (Cyprinodontiformes), their structure, zoogeography, and systematics. Bull Am Mus Nat Hist 126:1-176

SAS Institute (2007) SAS Enterprise Guide 4.1: SAS OnDemand for academics. SAS Institute, Cary, NC

Sibly RM (1999) Efficient experimental designs for studying stress and population density in animal populations. Ecol Appl 9:496-503

$>$ Sibly RM, Calow P (1989) A life-cycle theory of responses to stress. Biol J Linn Soc 37:101-116

Stearns SC (1983) The evolution of life-history traits in mosquitofish since their introduction to Hawaii in 1905: rates of evolution, heritabilities, and developmental plasticity. Am Zool 23:65-75

Stearns SC (1992) The evolution of life histories. Oxford Uni- 
versity Press, Oxford

Stearns SC, Sage RD (1980) Maladaptation in a marginal population of the mosquito fish, Gambusia affinis. Evolution 34:65-75

Titus JG, Richman C (2001) Maps of lands vulnerable to sea level rise: modeled elevations along the US Atlantic and Gulf coasts. Clim Res 18:205-228

Trexler JC, Travis J (1990) Phenotypic plasticity in the sailfin molly, Poecilia latipinna (Pisces, Poeciliidae). 1. Field experiments. Evolution 44:143-156

Turner CL (1941) Morphogenesis of the gonopodium in Gambusia affinis affinis. J Morphol 69:161-185

Editorial responsibility: Thomas Turner,

Albuquerque, New Mexico, USA
Van Horne B (1983) Density as a misleading indicator of habitat quality. J Wildl Manag 47:893-901

Visser JM, Sasser CE, Chabreck RH, Linscombe RG (1998) Marsh vegetation types of the Mississippi River deltaic plain. Estuaries 21:818-828

Wedemeyer GA, Barton BA, McLeay DJ (1990) Stress and acclimation. In: Schreck C, Moyle P (eds) Methods for fish biology. American Fisheries Society, Bethesda, MD, p 451-489

Winemiller KO, Rose KA (1992) Patterns of life-history diversification in North American fishes: implications for population regulation. Can J Fish Aquat Sci 49:2196-2218

Submitted: January 19, 2009; Accepted: October 21, 2009

Proofs received from author(s): December 9, 2009 